\title{
研究ノート
}

\section{食事及び食品たんぱく質のアミノ酸スコア(FAO 1973)}

The Amino Acid Score of Proteins in Diet and Food in Japan

\author{
その1. 日本人摄取たんぱく質のアミノ酸スコア
}

Part 1. The Amino Acid Score of Proteins Ingested by the Japanese People

国立栄養研究所 (National Institute of Nutrition)

松 野 信 郎 (Nobuo Matsuno)

There are many kinds of the chemical scoring methods to estimate the nutritive value of protein in food and diet. Recently, the new chemical scoring method, which is called "Amino Acid Score", was proposed by the Joint of FAO and WHO Energy and Protein Requirement Committee in 1973.

Therefore, the amino acid score of protein consumed by the Japanese people was calculated from the data of the National Nutrition Survey conducted in Japan in 1971.

The results are shown as follows:

In comparing the amino acid pattern of the Japanese diet with the FAO's new reference pattern of amino acid, sonly threonine was the limiting amino acid among the eight essential amino acids. Thus the amino acid score of the Japanese diet based on the amounts of all essential amino acids was 98 and the most limiting amino acid was found to be threonine. But the score based on the amounts of three amino acids (lysine, tryptophan and the total of sulfur containing amino acids) calculated was 100 .

食品たんぱく質の栄養価を, アミノ酸組成より推定する化学的評価法は種々考案されている。なかでもFAO たんぱく質必要量委員会は, 1957年人体アミノ酸必要量パターンを比較基準とするたんぱく価法 (Protein score)を提唱した ${ }^{11}$ 。その後 FAO とWHO の共同専門委員会は, 1965年に舀卵や人乳のアミノ酸パターン を基準とし，A/E 比（必須アミノ酸/必須アミノ酸総計）を比較するケミカルスコア法を提案した ${ }^{2)}$ 。しか し，また最近同委員会は，たんぱく質評洒法として新たにアミノ酸スコアを求める方法を，その熱量及びたん ぱく質必要量報告 ${ }^{3)}$ で示している。

このアミノ酸スコアは, 1957年のたんぱく価を求める方法と非常によく似ている。比較基準は主として人体 アミノ酸必要量推定値を基礎とし, 幼児が正常に成長するための十分量の乳や, 各種豰類たんぱく質のアミ, 酸量を考虑に入れて作製したアミノ酸パターンであり, 計算方法もたんぱく価法と非常に似ている。

著者はすでに，日本人の摂取たんぱく質や食品たんぱく質の化学価について種々検討報告してきたが，今回 は新たに提案されたアミノ酸スコアを日本人摂取たんぱく質について試算したので報告する。

万法

a）比較基準アミノ酸パターン 
アミノ酸スコアを求めるための, 比較基準アミノ酸パターンを表 1 に示した。1957年の基準パターンと比較 して明らかな相違は, トリプトファンと含硫アミノ酸の減少である。またりジン，スレオニン，ロイシンも若 干ふえている。しかしスレオニ ンとリジン, 又はロイシンとの 比は両パターン共ほとんど変っ ていない。このパターンのE/T 比は, 乳児のアミノ酸必要量パ ターンの $\mathrm{E} / \mathrm{T}$ 比に近い。そし て1957年のパターンより幾分高 いが，鵎卵や人乳のそれよりか なり低い。な抗このパターンは 暫定的なものであり, 今後の研 究の進展により変り得ることを 同委員会恃述べている。

b) アミノ酸スュア算出方法 算出方法は，たんぱく価 ${ }^{1)}$ 表 1 新しいFAO の暫定アミノ酸パターン

\begin{tabular}{|c|c|c|c|c|c|}
\hline \multirow{2}{*}{ アミノ酸 } & \multicolumn{2}{|c|}{$\begin{array}{c}\mathrm{FAO} \text { パターン } \\
\text { (1973) }\end{array}$} & \multirow{2}{*}{$\begin{array}{l}\text { FAO } \\
\text { パターン } \\
\text { (1957) } \\
\mathrm{mg} / \mathrm{Ng}\end{array}$} & \multirow{2}{*}{$\begin{array}{l}\text { 鶏 卵 } \\
\mathrm{mg} / \mathrm{Ng}\end{array}$} & \multirow{2}{*}{$\begin{array}{l}\text { 人乳 } \\
\mathrm{mg} / \mathrm{Ng}\end{array}$} \\
\hline & $\mathrm{mg} /$ ばく & $\mathrm{mg} / \mathrm{Ng}$ & & & \\
\hline Ile & 40 & 250 & 270 & 330 & 320 \\
\hline Leu & 70 & 440 & 306 & 530 & 610 \\
\hline Lys & 55 & 340 & 270 & 440 & 420 \\
\hline Met + Cys & 35 & 220 & 270 & 380 & 220 \\
\hline Phe+Tyr & 60 & 380 & 360 & 560 & 580 \\
\hline Thr & 40 & 250 & 180 & 290 & 270 \\
\hline $\operatorname{Trp}$ & 10 & 60 & 90 & 100 & 100 \\
\hline Val & 50 & 310 & 270 & 410 & 370 \\
\hline 合 計 & 360 & 2,250 & 2,016 & 3,040 & 2,890 \\
\hline
\end{tabular}

注 : 鷄卵, 人乳のアミノ酸組成は日本食品アミノ酸組成表 (1966) の数 值を用いた

$\mathrm{A} / \mathrm{T}$ 比化学価 ${ }^{4)}$ を求める方法と同様で, 同報告書 ${ }^{3)}$ によると,

$$
\text { アミノ酸スコア }=\frac{\text { 試験たんぱく質 } 1 \mathrm{~g} \text { 当りのアミノ酸 } \mathrm{mg}}{\text { 比較基準のアミ酸 } \mathrm{mg}} \times 100
$$

とし, 最小のもの（第一制限アミノ酸）をアミノ酸スコアとしている。そしてスコアの計算には, 差し当りリ ジン，含硫アミノ酸及びトリプトファンについて行光ば良いとしている。これらのアミノ酸は，大部分の食品 や食慨の第一制限アミノ酸となるからである。

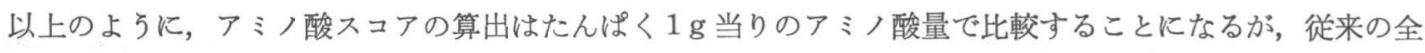
窒素当りのアミノ酸量を比較するよりる実際的であると考光られる。しかし, 現在食品のアミノ酸含量表は, 日本5) のものにしても $\mathrm{FAO}^{6)}$ のそれにしてもたんぱく $\mathrm{g}$ 当りでなく, $\mathrm{N} 1 \mathrm{~g}$ 当りのアミノ酸量で表示されて 扣り, また各種化学価の計算にも $\mathrm{N} 1 \mathrm{~g}$ 当りのアミノ酸量の比較を行ってきたので, この報告では $\mathrm{N} 1 \mathrm{~g}$ 当り のアミノ酸パターンで比較した。また比較は 8 種の全必須アミノ酸について行ったが, アミノ酸スコアは原則 として 3 種のアミノ酸 (リジン, 含硫アミノ酸, トリプトファン) のスコアで示した。前記 3 アミ酸以外が 第一制限アミノ酸になる場合は併記した。

c）計算に用いた資料

(1)昭和46年度国民栄養調査成績より算出した日本人必須アミノ酸摂取量7), 及び(听日常摂取している食餉献 立を模型化した食品混合物 ${ }^{8)}$, ( ) 日本人の平均的な摄取食物たんぱく質の栄養価を推定するための 23 種類の食 品混合物 ${ }^{8)}$ である。

なおこれらの計算には, 日本食品アミノ酸組成表(5) を用いた。

\section{結果}

日本人摂取たんぱく質のアミノ酸パターンと, FAO のパターンを比較すると，表 2 に示す通りであり，ス 
表 2 日本人摂取たんぱくのアミノ酸スコア （昭和46年度国民栄養調査成績より算出）

\begin{tabular}{|c|c|c|c|}
\hline アミノ酸 & $\begin{array}{l}\text { 日本人 } \\
\text { 攝取たん } \\
\text { ぱく(A) } \\
\mathrm{mg} / \mathrm{Ng}\end{array}$ & $\begin{array}{c}\mathrm{FAO} \\
\text { パターン } \\
\text { (B) } \\
\mathrm{mg} / \mathrm{Ng}\end{array}$ & $(\mathrm{A}) /(\mathrm{B}) \times 100$ \\
\hline Ile & 286 & 250 & 114 \\
\hline Leu & 483 & 440 & 110 \\
\hline Lys & 366 & 340 & 108 \\
\hline Met + Cys & 227 & 220 & 103 \\
\hline Phe+Tyr & 526 & 380 & 138 \\
\hline Thr & 246 & 250 & 98 \\
\hline Trp & 78 & 60 & 130 \\
\hline Val & 335 & 310 & 108 \\
\hline 合 計 & 2,547 & 2,250 & \\
\hline
\end{tabular}

表 3 日本人摂取たんぱく質の各種化学価

\begin{tabular}{lc}
\hline \multicolumn{1}{c}{ 評 価 法 } & 化 学 価 \\
\hline たんぱく価 (FAO 1957) & $84(\mathrm{~S}) *$ \\
アミノ酸スュア (FAO 1973)** & 100 [98 Th] \\
A/E 比卵価 (FAO 1965) & $71(\mathrm{~S})$ \\
A/E 比人乳価 (FAO 1965) & $89(\mathrm{~T})$ \\
A/T 比卵価 & $59(\mathrm{~S})$ \\
EAA-index & 82
\end{tabular}

* 第一制限アミノ酸を示す $(\mathrm{S}=$ 含硫アミノ酸, $\mathrm{T}=$ リプトファン, $\mathrm{Th}=$ スレオニン)

**アミノ酸スコアは, 3 種アミノ酸 (リジン, 含硫 アミノ酸, トリプトファン)を比較したスコア と，8種のアミノ酸を比較したスコアは[〕内と を佯記した
レオニンが98で, 他の 7 種 のアミノ酸はいす゚れも 100 を越えている。したがって アミノ酸スコアをリジン， 含硫アミノ酸, トリプトフ アンの 3 者の内, 最低のも のとすれば，日本人摂取た んぱく質のアミノ酸スコア は100 となる。またもし， 全必須アミノ酸を比較した としても，スレオニンだけ が制限アミノ酸となり，ア ミノ酸スコアは98となる。 同パターンについて各種の 化学価を算出したが7)，こ のアミノ酸は他の化学価よ りかなり高いようである （表 3 )。

つぎに, 日本人の摂取食
表 4 日本人摂取たんぱく質のアミノ酸スュア（その 2 食品混合物）

\begin{tabular}{|c|c|c|c|c|}
\hline $\boldsymbol{\gamma}$ & ミ， 酸 & $\begin{array}{c}\mathrm{FAO} \text { (1973) } \\
\text { (190ターン }\end{array}$ & $\begin{array}{l}\text { 混合 物 A } \\
\text { (動蛋40\%) }\end{array}$ & $\begin{array}{l}\text { 混合物 B } \\
\text { (動蛋 } 0 \%)\end{array}$ \\
\hline \multirow{9}{*}{$\begin{array}{c}\text { ア } \\
\vdots \\
j \\
\text { 酸 } \\
\text { 品 } \\
\text { タ } \\
1 \\
y \\
\text { mg } \\
\text { Ng }\end{array}$} & Ile & 250 & 278 & 266 \\
\hline & Leu & 440 & 472 & 470 \\
\hline & Lys & 340 & 359 & 243 \\
\hline & Met +Cys & 220 & 236 & 226 \\
\hline & Phe+Tyr & 380 & 527 & 534 \\
\hline & Thr & 250 & 239 & 220 \\
\hline & $\operatorname{Trp}$ & 60 & 81 & 78 \\
\hline & Val & 310 & 335 & 337 \\
\hline & 合 計 & 2,250 & 2,527 & 2,374 \\
\hline \multirow{3}{*}{ 化 } & アミノ酸スコア & & $100[96(\mathrm{Th})]$ & $72(\mathrm{~L})$ \\
\hline & たんぱく価 & & $87(\mathrm{~S})$ & $84(\mathrm{~S})$ \\
\hline & A/E 比卵価 & & $74(S)$ & $70(\mathrm{~L})$ \\
\hline \multirow[t]{2}{*}{ 学 } & $\mathrm{A} / \mathrm{E}$ 比人乳価 & & 89 (Le) & $7 \theta(\mathrm{L})$ \\
\hline & A/T 比卵価 & & $62(S)$ & $55(\mathrm{~L})$ \\
\hline \multirow[t]{2}{*}{ 価 } & EAA-index & & 81 & 76 \\
\hline & 生物価(実測値) & & $86(\mathrm{~S})$ & 71 (L) \\
\hline
\end{tabular}

注 $1:$ （）内は第一制限アミノ酸を示す ( $\mathrm{L}=$ リジン, Le=ロイシン, $\mathrm{S}=$ 含硫アミノ酸, $\mathrm{T}=$ トリプトファン, $\mathrm{Th}=$ スレオニン)

注 $2:$ アミノ酸スコアは, 3 種のアミノ酸 (リジン, 含硫アミノ酸, トリプ トファン）を比較したもの，8種のアミノ酸を比較したスュアは〔 ]に併 記した

物たんぱく質の栄養価を推定するために用いた食品混合物のアミノ酸スコアを求め, 表 4 に示したが, この混

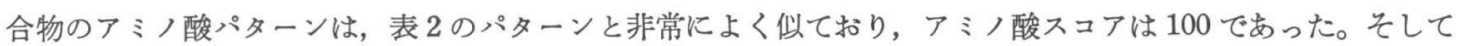
この混合物より動物性たんぱく質を除いた混合物（表 4 混合B）のアミノ酸スコアは72で，制限アミノ酸はリ ジンであった。この 2 種類の混合物の生物価のシロネズミによる測定值は, それぞれ86と71であった が，化 学価によっては混合物 $\mathrm{A}$ と B との間にはっきりした差異を示さなかったものが認められた。これに対し，アミ 
酸スコアは, 両混合物の差異を示

している。

われわれが日常摂取している食 事献立を模型化した食品混合物の アミノ酸スコアを計算すると, 表 5 に示す通りである。（各混合物 のアミノ酸パターン, 及び各種化 学価は文献 8 を参照) 小麦粉やパ ンに対する他のたんぱく添加によ る栄養価改善は, アミノ酸スコア でもたんぱく価でも推定出来るが， 米に対して大豆を補ってもたんぱ く価はほとんど変らず，更に豚肉 を足してる変化がみとめられなか
表 5 食品混合物のアミノ酸スコア

\begin{tabular}{|c|c|c|c|}
\hline \multirow[b]{2}{*}{ 混 } & \multicolumn{2}{|c|}{$ア ミ ノ$ 酸スコア } & \multirow[b]{2}{*}{ たんぱく価 } \\
\hline & $\begin{array}{c}3 \text { 種アミノ } \\
\text { 酸 比 較 }\end{array}$ & $\begin{array}{c}8 \text { 種アミノ } \\
\text { 酸 比 較 }\end{array}$ & \\
\hline 白米120 g & $62(\mathrm{~L})$ & $62(\mathrm{~L})$ & $78(\mathrm{~L})$ \\
\hline 白米十大豆 $20 \mathrm{~g}$ & $94(\mathrm{~L})$ & $94(\mathrm{~L})$ & $79(\mathrm{~S})$ \\
\hline 白米十大豆十豚肉 $50 \mathrm{~g}$ & 100 & 100 & $82(S)$ \\
\hline 小麦粉70g & $44(\mathrm{~L})$ & $44(\mathrm{~L})$ & $56(\mathrm{~L})$ \\
\hline 小麦粉+そば粉30 g & $68(\mathrm{~L})$ & $68(\mathrm{~L})$ & $76(S)$ \\
\hline 小麦粉十そば粉十鵎卵 $50 \mathrm{~g}$ & $92(\mathrm{~L})$ & $92(\mathrm{~L}, \mathrm{Th})$ & $96(\mathrm{~T})$ \\
\hline パン100g & $35(\mathrm{~L})$ & $35(\mathrm{~L})$ & $44(\mathrm{~L})$ \\
\hline パン＋牛乳200 g & $78(\mathrm{~L})$ & $78(\mathrm{~L})$ & $70(\mathrm{~S})$ \\
\hline パン十牛乳十豚肉 $50 \mathrm{~g}$ & $94(\mathrm{~S})$ & $92(\mathrm{Th})$ & $76(\mathrm{~S})$ \\
\hline パン十牛乳十鶏卵50 g & $94(\mathrm{~L})$ & $92(\mathrm{Th})$ & $92(\mathrm{~S})$ \\
\hline パン+牛乳+肉+卵 & 100 & $97(\mathrm{Th})$ & $96(\mathrm{~T})$ \\
\hline
\end{tabular}

注 : ( )内は第一制限アミノ酸を示す $(\mathrm{L}=$ リジン, $\mathrm{S}=$ 含硫アミノ

酸, $\mathrm{T}=$ トリプトフアン, $\mathrm{Th}=$ スレオニン)

った。しかしアミノ酸スコアでは, 明らかに補足効果が推定された。このことは, 前述の食品混合物 $\mathrm{A} B$ B持 ける場合と同様の傾向である。

以上のように, FAO より提案されたアミノ酸スコア法によって算出された日本人摂取たんぱく質の（化学 的）栄養価は，非常に高く100 と推定された。この結果は，従来算出された種々の化学価の数值中，最高值で ある。たしかに, 最近の日本人の食生活は量質共に著しく向上し，食事たんぱく質の栄盖価の向上も異論のな いところである。しかし，このアミノ酸スコアほどに高い栄養価を持っているであろうか。もちろん,このア ミノ酸スコアの算出には食品のアミノ酸含量の正確度, アミノ酸利用率なと゚化学価推定時における共通の問題 点が考慮されていないが，同時に基準アミノ酸パターンや， $\mathrm{E} / \mathrm{T}$ 比などの妥当性について十分明らかでな い。したがって, 少なくとも基準アミノ酸パターンや $\mathrm{E} / \mathrm{T}$ 比の妥当性について, 動物実験や人体実験により 十分検討された上で，このアミノ酸スコア法を一般的に用いるか否か決定すべきであろう。

\section{要 約}

たんぱく質の栄養価評価法として, 最近, FAO よりアミノ酸スコア法が提案されたが，日本人の摂取たん ぱく質のアミノ酸スコアを最近の国民栄養調査成績より算出した。その結果, 新しい基準アミノ酸パターンに 対して摂取たんぱく質のアミノ酸パターンは,スレオニンが98で僅かに低かっただけであっだ。したがって， 日本人摂取たんぱく質のアミノ酸スコアは非常に高く，3種類のアミノ酸（リジン，含硫アミノ酸，トリプト ファン）比較では 100 , 全必須アミノ酸比較でも 98 となった。

その他，数種食品混合物についてアミノ酸スコアを算出し，たんばく価などと比較を行った。

文献

1） FAO蛋白必要量委員会報告: 蛋白質必要量 (吉村訳), 第一出版 (1957)

2) $\mathrm{FAO} / \mathrm{WHO}$ 共同専門委員会報告 : 蛋白質必要量 (必須アミノ酸研究委員会訳), 第一出版 (1965)

3) Report of a Joint FAO/WHO Ad Hoc Expert Committee : "Energy and Protein Requirement", 
FAO/WHO (1973)

4) H. H. Mitchell \& R. J. Block : J. Biol. Chem., 163, 599 (1946)

松野, 深味, 飯沼 : 栄養学雑誌, 30, 35 (1972)

5）科学技術庁資源局：日本食品アミノ酸組成表，(1966）

6） FAO : 食品のアミノ酸含量とその蛋白生物価 (大礒訳), 第一出版 (1972)

7) 松野: 栄養学雑誌, 31, 122 (1973)

8）松野, 松野: 栄養学雑誌, 30, 136 (1972)

9）松野, 岩谷, 田村 : 栄養学雑誌, 29, 250 (1970)

（受付 : 昭和 48 年12月10日） 